\title{
ABSORPTIVE CAPACITY: AN ANALYSIS IN THE CONTEXT OF BRAZILIAN FAMILY FIRMS ${ }^{1}$
}

\section{GLORIA CHARÃO FERREIRA}

Master's Degree in Management from the Department of Management at the Universidade Potiguar (UnP).

Doctorate Student in Management from the Department Management and Economics at the Universidade da Beira Interior.

Estrada do Sineiro, s/n, Polo IV, Covilhã, Castelo Branco - Portugal - CEP 6200-209

E-mail: gcfconsultoria@gmail.com

\section{JOÃO JOSÉ MATOS FERREIRA}

Doctor in Management from the Department Management and Economics at the Universidade da Beira Interior. Associate Professor for the Department of Management and Economics \& NECE Research Unit at the Universidade da Beira Interior.

Estrada do Sineiro, s/n, Polo IV, Covilhã, Castelo Branco - Portugal - CEP 6200-209

E-mail: jjmf@ubi.pt

1 We thank the Coordenação de Aperfeiçoamento de Pessoal de Nível Superior (Capes) for granting a scholarship to the first author. 


\section{ABSTRACT}

Purpose: The purpose of this study is to analyze the capacity of family firms to absorb relevant information from their surrounding environments, and incorporate it in their innovative activities. The study also seeks to improve our understanding if, and in what ways, the generational diversity in firm's management is an important resource.

Originality/gap/relevance/implications: In spite of the relevance of this matter, few scholars have explored the relationship between absorptive capacity (Acap) and family firms. On the other hand, the economic importance of these firms is reported, for example, in Leone (2005) and Machado, Grzybovski, Teixeira and Silva (2013), authors reporting that approximately $90 \%$ of Brazilian firms are controlled by families, being the fastest-growing business segment.

Key methodological aspects: The sample consists of 241 family firms. The SmartPLS software is used for structural equation modeling.

Summary of key results: The results show that Acap is an important predictor for the innovation performance of family firms. Contrary to expectation, the involvement of several generations in the management of the family firms is not a significant moderator between ACAP and innovation performance.

Key considerations/conclusions: This study fills an important gap in the research on family firms, once, by taking into consideration the generational diversity in the management of these firms, its results deepen our understanding of the essential features of a family business, and analyze the innovation in an intergenerational perspective.

\section{KEYWORDS}

Absorptive capacity. Family firms. Generational diversity. Innovation performance. Dynamic capacity. 


\section{INTRODUCTION}

The innovation process demands from firms the allocation of resources and capabilities for the transfer of external knowledge to be successful. In this sense, an important aspect of the process of knowledge creation and innovation is the ability of the firm to absorb external knowledge herein referred to as absorptive capacity (Acap).

Although the innovation performance can be influenced by other factors, such as, size, characteristics of management, among others, Acap has been identified as an important element to understand the differences in the use of knowledge and its application in innovation (Zahra \& George, 2002; McCann \& Folta, 2008).

Since the 1990's, the debate about the Acap has been developed and it has driven attention of many investigators (Cohen \& Levinthal, 1990; Zahra \& George, 2002; Lane, Koka, \& Pathak, 2006; Jones, 2006; Vega-Jurado, Gutiérrez-Gracia, \& Fernándes-De-Lucio, 2008; Vega-Jurado, Gutiérrez-Gracia, Fernández-De-Lucio, \& Manjarrés-Henríquez, 2008; Camisón \& Forés, 2010; Flatten, Engelen, Zahra, \& Brettel, 2011; Burcharth, Lettl, \& Ulhøi, 2015).

Initially, Cohen and Levinthal $(1989,1990)$ point to Acap as the firm's ability to recognize the value of new information and knowledge, assimilate them and apply them for commercial purposes. Their studies provide an important contribution and are considered as a reference in this area, despite of the fact that they restricted the concept to firms that develop internally research and development activities (R\&D).

Seeking to analyze the multidimensional nature of the concept, Zahra and George (2002) visualize the Acap as a dynamic capability through which firms acquire, assimilate, transform, and exploit external information and, therefore, it is an essential prerequisite to implement innovation processes.

From this perspective to be referred as a dynamic capability, the authors call attention to the firm's needs to invest in Acap, to the extent that the mere exposure to a variety of potential sources of innovation does not give you the assurance that it will have the capacity to acquire and assimilate information, nor it will transform and be applied in their activities related to innovation (Zahra \& George, 2002). Thus, as pinpointed in the literature, the firms differ significatively in innovation capacity due to differences in their ability to absorb external information (Cohen \& Levinthal, 1990; Zahra \& George, 2002; Nieto \& Quevedo, 2005). 
However, despite the relevance of the theme, few scholars have explored the relationship between Acap and family firms. On the other hand, the economic importance of these firms is reported, for example, in Leone (2005) and Machado, Grzybovski, Teixeira and Silva (2013), authors reporting that approximately $90 \%$ of Brazilian firms are controlled by families, generating more than two million direct jobs, being the fastest-growing business segment. Likewise, the European Family Businesses (European Family Businesses, 2014) estimates that $65 \%$ to $80 \%$ of firms in the European Union are family firms, representing $40 \%$ to $50 \%$ of jobs in the private sector.

In addition to its importance in economic development, some scholars point out that this type of firm has a unique strategic, managerial and organizational nature that makes it distinct in relation to non-family firms (Vries, Carlock, \& Florent-Treacy, 2009; Machado et al., 2013). Then, it is possible to find empirical evidence to report negative and positive associations, such as between innovation and family firms.

On the one hand, i.e., negative associations, authors report that family firms invest less in R\&D (Chrisman \& Patel, 2011; Block, 2012; Choi, Zahra, Yoshikawa, \& Han, 2015), and others have even suggested that these firms use internal resources more, involving itself little in external collaboration processes (Roessl, 2005) due to being averse to risks when compared to non-family firms (Classen, Van Gils, Bammens, \& Carree, 2012). The reason for this reluctance is that the family firms owners are resistant to relinquish control over the firm, for fear of jeopardizing its socio-emotional richness (Gómez-Mejía, Takács Haynes, Núñez-Nickel, Jacobson, \& Moyano-Fuentes, 2007; Cennamo, Berrone, Cruz, \& Gómez-Mejía, 2012). This fact leads family firms to maintain its focus on a non-financial goal, which makes investment in innovation limited in this type of organization (König, Kammerlander, \& Enders, 2013; Gómez-Mejía, Campbell, Martin, Hoskisson, Makri, \& Sirmon, 2014).

On the other hand, there are studies that indicate that despite family firms present a limited innovation input, they can overcome this limitation through their ability to transform and exploit these entries, as they benefit from resources and capabilities that eventually favor and promote innovation (Cennamo et al., 2012; Carnes \& Ireland, 2013). To exemplify these particulars, authors have pointed out that in family firms it is remarkable the concern with non-financial goals, such as creating and maintaining relationships based on trust and long-term connections with suppliers, customers, and other actors involved; privileged access to a network of partners resulting from tradition around the family name, and extended to the enter- 
prise; the involvement of different generations of the family (Gómez-Mejía et al., 2007; Cennamo et al., 2012; Kellermanns, Eddleston, \& Zellweger, 2012), which ultimately provide them with skills that will support the innovation process. Thus, taking into account these peculiarities and contradictions, it leads to understand the study of absorptive capacity in the context of family firms as a fertile ground for research.

Therefore, this research aims to analyze the capacity of family firms to absorb relevant information from the external environment, incorporating it in their innovative activities. Also, it tries to understand whether, and to what extent, the generational diversity in firm management, is configured as an important resource for firms here portrayed.

This article is structured as follows. First, it discusses the Acap in terms of its conceptual evolution, and its components. Subsequently, the relationship between Acap and innovation performance is discussed, as well as the themes of family firms and generational diversity. After that, the hypotheses are presented. The next section presents the methodological aspects and the results of the investigation. Finally, discussion, conclusion, and the limitations and recommendations for future research are exposed.

\section{ABSORPTIVE CAPACITY}

With the work of Cohen and Levinthal (1989), Acap started to be applied to the context of organizations, i.e., to the level of organizational analysis. From a conceptual point of view, Cohen and Levinthal (1989; 1990) understand it as the firm's ability to identify the value of information, assimilate and apply it for commercial purposes, which is critical to their innovative capacity.

With the studies of Zahra and George (2002, p. 186), the concept of Acap was magnified considering it as "a group of organizational routines and processes by which firms acquire, assimilate, transform and exploit knowledge to produce a dynamic organizational capability".

The model proposed by Zahra and George (2002), in addition to the distinction into two components or dimensions, namely, the Potential Absorptive Capacity (Pacap), which covers the skills of acquisition and assimilation, and the Realized Absorptive Capacity (Racap), which includes the capabilities of transformation and exploitation of knowledge (Chart 1). 


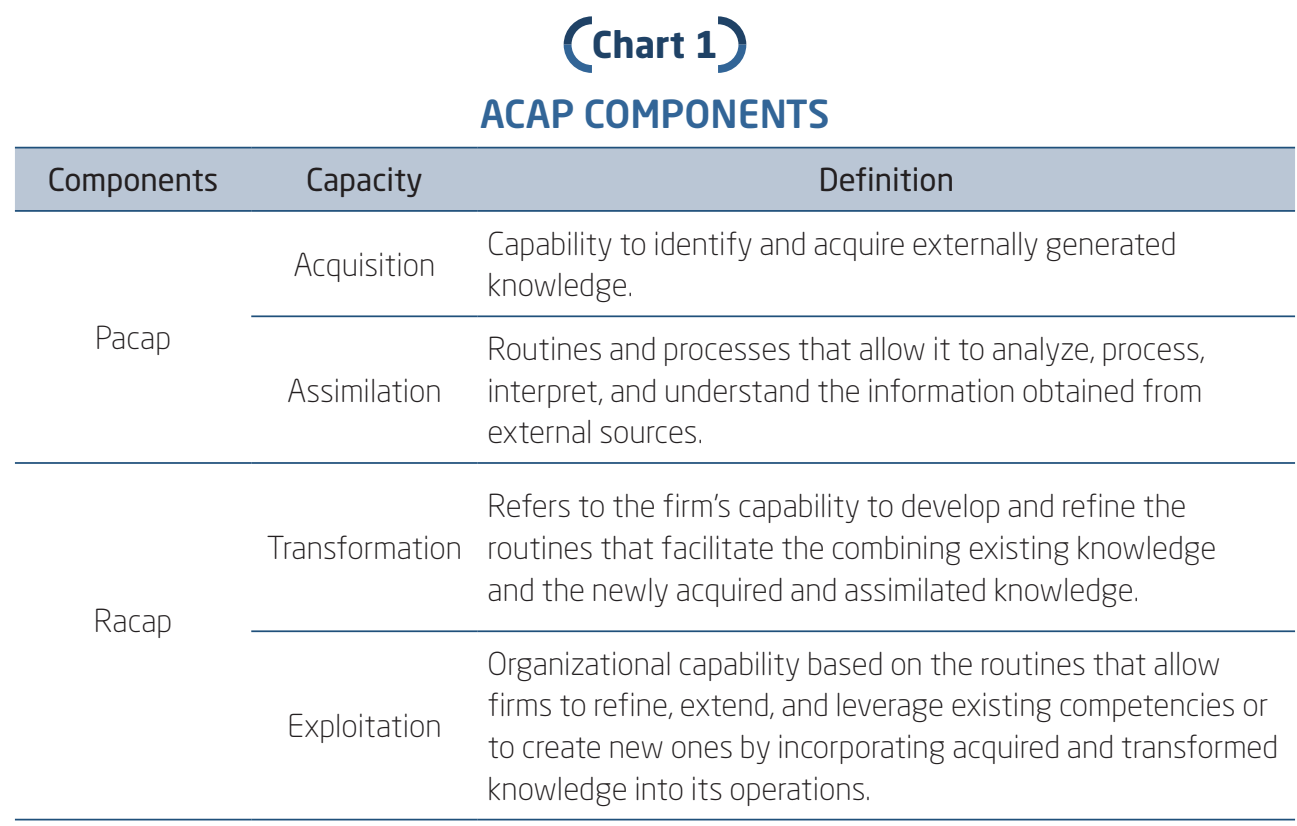

Source: Adapted from Zahra and George (2002).

Regarding the multidimensional aspect of Acap, Zahra and George (2002) point out that although its components have distinct roles, they are complementary. In other words, Racap depends on Pacap, since a firm must necessarily have the ability to acquire them and assimilate them to exploit the information from the external environment. However, studies point to the fact that a firm may have a high level of Pacap, but a low Racap, i.e., a low transformation capacity and application of new products and processes (Jansen, Van Den Bosch, \& Volberda, 2005; Fosfuri \& Tribó, 2008; Vega-Jurado et al., 2008).

Moving forward, the model presented by Zahra and George (2002) presents two antecedents and three moderating factors. The antecedents are the sources of complementary knowledge and experience of employees. For Zahra and George (2002), when it comes to external factors, firms must take into consideration that the simple fact of exposure to sources of information does not necessarily lead to the development of Pacap, especially if there is a low complementarity with the firms prior knowledge. According to Vinding (2006), the more education and training people receive, the greater their ability to absorb and use new knowledge. Thus, it is possible to think that Acap is dependent on the path, and that it has a cumulative nature, that is, resulting from the cumulative nature of knowledge (Cohen \& Levinthal, 1990; Zahra \& George, 2002). 
The moderating factors are the activation stimulators, being considered as the events that encourage or force the firm to respond to internal or external stimuli (crisis, technological changes etc.). Studies indicate the crises that threaten the existence of the organization and can evolve as potential enablers of learning, leading the firm to develop capacity that is designed for the acquisition, internalization and application of external knowledge (Winter, 2000; Zahra \& George, 2002). The mechanisms of social integration, which have the function of reducing the gap between Pacap and Racap. The third moderating factor mentioned by the authors is the appropriability regime, which relates to the firm's conditions to protect their innovations, since each sector has specific rules for the registration of patents for products and processes. According to Zahra and George (2002), Acap would provide a competitive advantage to the firm to the level of strategic flexibility, innovation and performance.

According to Zahra and George (2002), Pacap has received little attention from researchers, compared to Racap. They argue that Pacap offers firms the strategic flexibility that can help them to adapt in dynamic contexts. Thus, Pacap is perceived as a condition to achieve competitive advantage in innovation, but firms must also develop Racap in order to fully enjoy the benefits of Acap (Zahra \& George, 2002; Fosfuri \& Tribó, 2008). In this sense, some authors have pointed to Acap as an important element of support to the innovation process (Zahra \& George, 2002; Vega-Jurado et al., 2008; Murovec \& Prodan, 2009; Kostopoulos, Papalexandris, Papachroni, \& Ioannou, 2011; Patterson \& Ambrosini, 2015).

According to Tidd and Bessant (2015), innovation is something new that adds value, and the development of new values increases the firm's competitive position, being moved by their ability to form relationships, detect opportunities and benefit from them. Thus, for these authors, the innovation process consists of four phases and only firms that can deal efficiently with the whole process the innovation will be successful: 1. Search: where the firm analyzes the internal and external environment in order to detect relevant signals in the environment of opportunities for change; 2. Selection: based on the strategic orientation of the firm, decide which variants with more possibilities to assist their growth and development; 3. Implementation: where the firm transforms ideas into reality, applying energy and scarce resources to make something different; and 4. Value capture through innovation: where the firm needs to ensure that applied efforts are justified, taking into account the benefits resulted from innovation.

Actually, these considerations lead to design innovation no longer in a linear sequential logic and, to the extent that it involves an iterative process, i.e., innovation is the result of interaction between the firm and the envi- 
ronment (Ferreira, Raposo, \& Fernandes, 2013; Ferreira, Fernandes, Alves, $\&$ Raposo, 2015). On the other hand, it would be imprudent to think that due to the existence of an environment rich in opportunities for innovation, any firm could be able to detect them and use them effectively. Zahra and George (2002) discussed this scenario, identifying that the impact of Pacap on the innovation performance depends on the efficiency by which Racap is transformed.

A thorough review of the literature conducted by Lane et al. (2006) pointed out that innovation is recognized as a result of organizational learning and, due to this, it has been considered as a result of the Acap of firms. They also report the existence of a recursive relationship among the constructs, i.e., since Acap plays an important role in the speed, frequency and magnitude of the innovation, companies, as they get involved in this process, have their stock of knowledge increased.

From the foregoing, it is clear that innovation performance ends up being a measure of company's ability to achieve a desired result from their activities, considering family firms as the basis for this research, once their specific characteristics open discussion possibilities related to the effect of family involvement in the firm management.

\section{FAMILY INVOLVEMENT IN THE MANAGEMENT OF FAMILY FIRMS - THE PERSPECTIVE OF GENERATIONAL DIVERSITY}

The studies of Habbershon and Williams (1999) introduce the concept of familiness, and reveal that some phenomena arising from family relationships are deeply rooted in the management of firm resources, and through the influence of the business family, the firms managers are eventually influenced in its decision-making process.

As a result, it is possible to realize a set of studies that argue that family firms are more creative, proactive and innovative than non-family firms (Nordqvist \& Melin, 2010; Kellermanns, Eddleston, Sarathy, \& Murphy, 2012), that they are characterized by a specific culture, and that would act innovatively trying to maintain a balance between stability and renewal (Mahmoud-Jouini \& Mignon, 2009).

On the contrary, other authors report that family firms that have a high degree of family involvement are characterized by more rigid mental models, and that they may also manifest an averse behavior to the creation and adoption of innovation due to the strong desire for continuity, and to the unk- 
nown possible effects on the socio-emotional wealth of the firm (Gómez-Mejía, et al., 2007; Miller, Le Breton-Miller, \& Lester, 2010; Kellermanns, et al., 2012; Schulze \& Kellermanns, 2015).

Particularly, the literature indicates that many managers of family firms fall into the trap called "strategic simplicity", i.e. cling to the past, despite the need for change (Ward, 2004). Other authors report in their studies the paradoxical tensions present in family firms, for example, the "Tradition $\mathrm{X}$ Change", as many of these companies face difficulties in adapting to a dynamic environment and, at the same time, uphold incorporated values, which frustrates the decision making and prevents innovation (Ingram, Lewis, Barton, \& Gartner, 2016).

Furthermore, the active presence of family in business has been investigated in terms of engagement among generations, that is, the simultaneous engagement of several generations in family firms. In this perspective, the survival of family firms through generations depends on its entrepreneurial capacity to enter into new markets, as well as its revitalization capacity. Thus, the role of the founder undergoes changes to the extent that subsequent generations participate in the business, providing opportunities for new knowledge and different points of view, from such diversity (Sciascia, Mazzola, \& Chirico, 2013; Filser, Brem, Gast, Kraus, \& Calabrò, 2016).

Similarly, authors like Salvato (2004), Ling and Kellermanns (2010) and Chirico, Sirmon, Sciascia and Mazzola (2011) report that while a single generation in charge of the company can perceive the innovation as a difficult activity to be developed, knowledge and diverse experience of several generations can lead the company to have other perspectives of this process.

For Gersick, Davis, Hampton and Lansberg (2006), and Zahra, Neubaum and Larrañeta (2007), multigenerational involvement strengthens the relationship between the mechanisms of sharing of formal and informal knowledge and technological capabilities of family firms, and the results suggest that this exchange of knowledge is richer when compared among family members within the same generation. In contrast, Kellermanns and Eddleston (2006), in a study focusing on corporate entrepreneurship in family firms, report they found in their results no evidence for a positive and significant association between involvement inter-generational and entrepreneurship.

From the foregoing, it is assumed that Acap has an important role in the innovation performance of family firms, and that the generational diversity in the management of family firms ultimately provide them the capacity to implement the benefits from Acap, in which it is formulated the following research hypotheses: 
H1: The Acap of firms has a positive and significant effect on innovation performance.

H2: Generational diversity moderates the relationship between Acap and firms innovation performance.

\section{METHODOLOGY}

This section highlights the research methodology, namely, the sample selection, data collection method, description and operationalization of variables, and the data analysis method.

\subsection{Sample}

It is adopted in this study the criterion of ownership/management, i.e., it is considered a family firm one whose family owns more than $50 \%$ ownership of the company and is responsible for managing it (Astrachan \& Kolenko, 1994). In this study, it was chosen the probability sampling, where samples are taken randomly (Marôco, 2014). That way, in order to have access to the companies it is used the registration of the Federation of Industries of Rio Grande do Sul (Federação das Indústrias do Estado do Rio Grande do Sul, 2015), which contains 10.980 registered firms. From this population, it defined the sample size. At this early stage, it was found that 2,975 firms lacked contact e-mail, and a necessary condition for the data collection. Thus, the study counts on the number of 8,005 companies with e-mails, to which the survey link was sent. The questionnaire was created and made available to respondents through the Platform Google Forms. The link was sent to the managers of firms, as it is believed that the way the resources and capabilities are evaluated, purchased, built, allocated and exploited, susceptible to decisions taken by the representatives of the firms concerned. Data collection took place between October 2015 and January 2016. It was obtained the return of 273 companies, of which 241 were considered family firms.

For greater accuracy in estimating a minimum sample size, the statistical power of the sample size was evaluated, which was like a priori, using the G*Power 3.1.9.2 program (Faul, Erdfelder, Lang, \& Buchner, 2007). The minimum sample size suggested by $\mathrm{G}^{*}$ Power was 55 cases, but as a suggestion to have a more consistent model, it is interesting to use double 
or triple that amount (Ringle, Silva, \& Bido, 2014). Thus, the size of this sample $(n=241)$ has statistical power to detect the existence of an alleged relationship when it actually exists.

\subsection{Mensuration}

The conceptual model of this study is presented in Figure 1 where the theoretical relationship was established between the constructs, namely, Acap, innovation performance, and generational diversity.

\section{(Figure 1)}

CONCEPTUAL MODEL

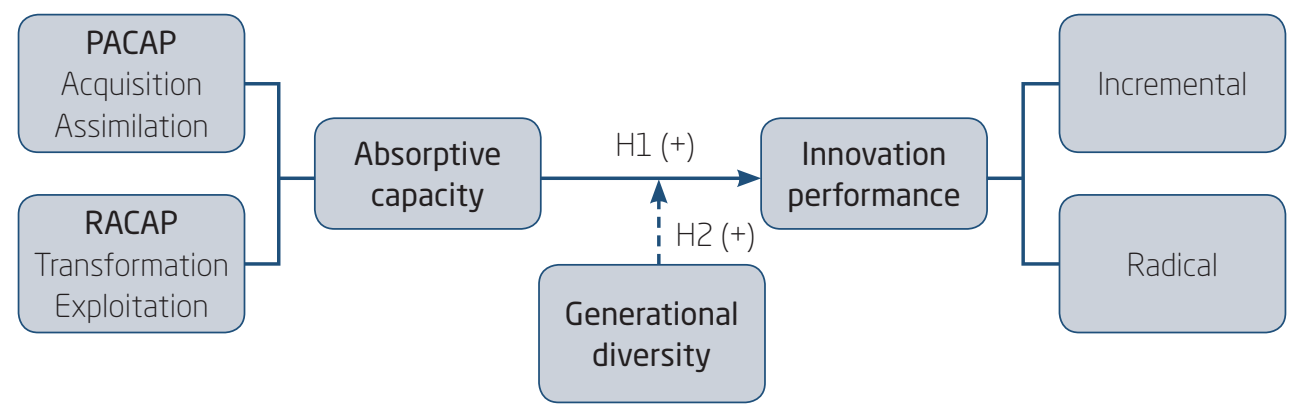

Source: Elaborated by the authors.

Predictive variable - In order to capture the Acap, it was used a structured questionnaire developed by Flatten et al. (2011), composed by 14 items with Likert 7 point scale $(1=$ Totally Disagree to $7=$ Totally Agree $)$. This instrument is validated in the Brazilian context (Santos, 2013; Vicentin, 2015), and its use and justification are guided on solid theoretical and conceptual bases.

Dependent variable - For this variable, it is considered the answer "No" = 0, as there was no innovation, and "Yes" = the absolute number corresponding to the innovation introduced by the firm.

Moderator variable - To operationalize this variable, three questions were developed and analyzed together: the first one of a dichotomous configuration, in which the respondent indicates whether there are in the firm different generations of family in management. Then, two multiple-choice questions seek to identify which generation(s) is/are responsible for managing the firm. It takes the value "0" when the respondent states that only 
one generation of the family is in the company's management, and " 1 " when the respondent refers to two or more generations (Miller, Le Breton-Miller, \& Lester, 2012).

Control variables - The control variables were selected based on the possible influence they have on the dependent and independent variables. The literature points out that the size and the age of firms are internal factors that can influence the Acap. (Sørensen \& Stuart, 2000; Zahra, 2005; Zahra et al., 2007; Kraiczy, Hack, \& Kellermanns, 2014; Forés \& Camisón, 2016). Due to the large variation in the number of employees among the firms in the sample, this variable was transformed. This way, the natural logarithm (Ln) of the number of employees is used to measure the size of researched organizations (Zahra, 2003; Zahra, Hayton, \& Salvato, 2004; Zahra et al., 2007; Kraiczy et al., 2014). Similarly, with respect to the variable age of the firm, this variable was transformed as the age of the surveyed firms varies from 1 to 105 years old. Thus, using the values of quartiles, four discrete categories were created (under 15 years old, 16-24 years old, from 25-36 years old, over 37 years old), a procedure also adopted by other authors (Zahra, Hayton, Neubaum, Dibrell, \& Craig, 2008).

\subsection{Analysis}

The processing and data analysis were performed using SPSS statistical software version 22.0 for descriptive analysis, and the SmartPLS 2.0.M3 program (Ringle, Wende, \& Will, 2005) for the analysis of the measurement model and the structural model with Structural Equation Modeling technique. In order to meet the objectives of this study, a reflective model is estimated latent variables (LV) second order, which are modeled according to the Approach of Hierarchical Components (Wetzels, Odekerken-Schröder, \& Oppen, 2009; Hair, Hult, Ringle, \& Sarstedt, 2014). It is emphasized that the measurement of Acap as a reflective model is shared by previous studies (Flatten et al., 2011; Leal-Rodríguez, Roldán, Ariza-Montes, \& Leal-Millán, 2014; Wang, Senaratne, \& Rafiq, 2015; Hernández-Perlines, Moreno-Garcia, \& Yáñez-Araque, 2016).

\section{RESULTS}

This study included 273 companies, which were divided into two groups, i.e. family firms and non-family firms. The first group included 241 firms 
(88.3\%), and the second group included 32 firms (11.7\%). Considering the context chosen for this research, the companies belonging to the first group were in the analysis.

The average number of active employees in the sample is 59.10, and it was verified a wide range in this matter, with family firms ranging from a minimum of 1 employee up to a maximum of 829 employees. It was verified that $66(27.4 \%)$ family firms have less than 15 years of operation, followed by $61(25.3 \%)$ companies that have between 25 to 36 years. It is also possible to check that 59 family firms $(24.5 \%)$ have more than 37 years of existence, and that in the category of 16 to 24 years, were included $55(22.8 \%)$ of the sample.

With regard to the generational diversity, as described in the operation of this variable, it appears that in 126 family firms (52.3\%), two or more generations are responsible for the firm's management, and in 115 firms (47.7\%), one generation of the family is playing this role.

Regarding the question that focuses on identifying who was the founder of the firm, $80(33.2 \%)$ respondents chose the "father/mother", followed by $61(25.3 \%)$ that answered "yourself", also 59 (24.5\%) respondents indicated the option "other" (e.g. partnership between cousins, uncles, father in law, great-grandfather, etc.). These answers were followed by those who responded that the firm was founded by "Sibling/Siblings" and "Grandfather/ Grandmother", respectively, 22 (9.1\%) and 19 (7.9\%).

As for the fims operating sector, the most representative is the processing industry, with a number of $224(92.9 \%)$, in these it is observed the predominance of food products manufacturing industries $(16.1 \%)$, followed by beverage manufacturing industries $(11.2 \%)$, and the third incidence are the furniture manufacturing industries $(10.3 \%)$. The construction industry as well as the professional, scientific and technical activities had a smaller presence in our sample.

In order to characterize more specifically the generational diversity present in the management of family firms, it is considered important to discriminate which are the generations that coexist in the firm at the time of the study. Therefore, as for the generations involved in the firm's management, $88(36.51 \%)$ of family firms are being managed by the first generation of the family, and in $84(34.85 \%)$ there is simultaneous involvement of the first generation and second generation in the firm's management. It was also observed that family firms in this sample are distributed from first generation to firms in which the management is carried out by members of the fourth generation of the family, which is the lowest representation $(0.83 \%)$. 
As for generational presence on the administration board, there is a very similar situation from that presented in previous paragraph, in which 87 (36.10\%) of family firms reported that the first generation of the family is present on the board, and in $84(34.85 \%)$ there is a joint action of the first and second generations. It is noteworthy that $15(6.22 \%)$ of family firms reported that they do not have this board in its management system.

With respect to the level of education of respondents, 107 (44.4\%) have an undergraduate degree, $85(35.3 \%)$ reported having an graduate/MBA degree, followed by 31 (12.9\%) who reported having a high school level of education. Thus, as the position held by respondents, $76(31.5 \%)$ reported the position of "one of the managers", the second group of highest percentage was the "top managers", represented by 60 (24.9\%) managers, followed by position "CEO/General Director" indicated by 48 (19.9\%) of respondents. In turn, it was found that the average number of years in the firm corresponds to 2.38 years, with a standard deviation of 0.807 . In turn, the average time of leadership presented was 2.12 years, with standard deviation of 0.889 , and lastly, the working time in other firms was 1.85 years, with standard deviation of 0.813 .

\subsection{Measurement model}

The measurement model (outer model) is evaluated regarding convergent validity (Average Variance Extracted - AVE), reliability, and discriminant validity (criterion Fornell-Lacker and cross loadings) for reflective models (Hair et al., 2014).

Thus, in this verification process, it was observed the coefficients of the factor loadings for each indicator, from the LV first order and second order, in which those values greater than 0.6 were retained, since very low factor loadings may affect subsequent analyzes. In this first analysis, it was found that the indicators Aq1 (0.5694) and Ex1 (0.5930), LV of second order Acap, and indicator Aq1 (0.5999), LV of first order Pacap, were close to the critical value of 0.6. However, when tested the elimination of these indicators, it did not result in any increase in the composite reliability, and taking into consideration the recommendation of Hair et al. (2014) its composition remained unchanged. Likewise, DeVellis (2012) reports the importance of preserving the repeatability of the instrument, besides providing further comparative element in future studies, ensures that it does not suffer overfitting on the study sample.

Convergent validity and reliability were evaluated based on the AVE and the Composite Reliability (CR) of LV consecutively. According to Becker, 
Klein and Wetzels (2012), to verify the AVE and CR of LV second order, the researcher should use the path coefficients that connect them with their LV first order. As a result, the calculations were performed separately in an electronic spreadsheet, according to criteria of Garver and Mentzer (1999) and Hair, Tatham, Anderson and Black (2005). Chart 2 shows that all of AVE and $\mathrm{CR}$ values are above 0.50 , and 0.70 , respectively, allowing to state that the measurement model presents convergent validity and reliability.

\section{(Chart 2)}

AVERAGE VARIANCE EXTRACTED AND COMPOSITE RELIABILITY

\begin{tabular}{cccc}
\hline \multirow{3}{*}{ Second order } & LV & AVE & CR \\
\cline { 2 - 4 } & ACAP & 0.8679 & 0.9293 \\
\cline { 2 - 4 } & DIn & 0.7234 & 0.8395 \\
\cline { 2 - 4 } First order & PACAP & 0.5102 & 0.8787 \\
\cline { 2 - 4 } & RACAP & 0.6250 & 0.9207 \\
\cline { 2 - 4 } & InInc & 1 & 1 \\
\cline { 2 - 4 } Moderation & InRad & 1 & 1 \\
\cline { 2 - 4 } & DivGer & 1 & 1 \\
\hline \multirow{2}{*}{ Control } & CA* DivGer & 0.4812 & 0.9272 \\
\cline { 2 - 4 } & Age & 1 & 1 \\
\hline & Size & 1 & \\
\hline
\end{tabular}

Source: Elaborated by the authors.

Continuing with the analysis, the discriminant validity of the model was evaluated. It was verified that all the indicators of VL first order have higher values for the corresponding cross loadings, which ensures its discriminant validity. A second criterion is also adopted to verify discriminant analysis, considered more conservative, refers to the criterion Fornell-Larcker, in which the amounts in the main diagonal (square root of AVE) should be higher than the values in the respective rows, and columns (correlations), indicating the presence of discriminant validity (Hair et al., 2014). The values of the correlations between the LV are presented in Table 1, it is possible to verify that are smaller than the square root of AVE, confirming the discriminant validity. An exception was the correlation between Racap and Pacap that was greater than the square root of AVE, suggesting the lack 
of discriminant validity between them, nevertheless, as both LV are used as reflective indicators of the same construct (Acap), for this model, it does not qualify as a problem.

(Table 1)

CORRELATION MATRIX, DISCRIMINANT VALIDITY (FORNELL-LARCKER CRITERION)

\begin{tabular}{|c|c|c|c|c|c|c|c|}
\hline $\begin{array}{c}\text { LV First } \\
\text { Order }\end{array}$ & Age & DivGer & InInc & InRad & Pacap & Racap & Size \\
\hline Age & $N / A$ & & & & & & \\
\hline DivGer & 0.2118 & $\mathrm{~N} / \mathrm{A}$ & & & & & \\
\hline Inlnc & 0.1187 & 0.0520 & $N / A$ & & & & \\
\hline InRad & 0.0380 & 0.0458 & 0.4455 & $N / A$ & & & \\
\hline Pacap & 0.0668 & -0.0114 & 0.3238 & 0.2100 & 0.7142 & & \\
\hline Racap & 0.0259 & -0.0210 & 0.3896 & 0.1992 & 0.7387 & 0.7905 & \\
\hline Size & 0.3525 & 0.2021 & 0.2427 & 0.0899 & 0.1266 & 0.1121 & $\mathrm{~N} / \mathrm{A}$ \\
\hline $\begin{array}{l}\text { LV Second } \\
\text { Order }\end{array}$ & & Acap & & & & Din & \\
\hline ACAP & & 0.9316 & & & & & \\
\hline Din & & 0.3609 & & & & 0.8505 & \\
\hline
\end{tabular}

N/A = not applicable.

Note 1: Correlations equal or higher $|0.126|$ are significant $5 \%$, and correlations equal or higher $|0.166|$ are significant $1 \%$.

Note 2: The square root of AVE is distributed along the main diagonal, in bold.

Note 3: Fornell-Larcker criterion is not applicable to constructs measured with a single indicator (Sarstedt \& Ringle, 2010).

Source: Elaborated by the authors.

\subsection{Structural Model}

For the area of social and behavioral sciences, Cohen (1977, p. 413-414) suggests that $\mathrm{R}^{2}=2 \%$ be classified as small effect, $\mathrm{R}^{2}=13 \%$ as average effect and $\mathrm{R}^{2}=26 \%$ as great effect. The $\mathrm{R}^{2}$ of LV Pacap was 0.839 , i.e., this model may explain $83.9 \%$ of the variation component of Acap. Thus, $\mathrm{R}^{2}$ of Racap (89.7\%), InInc (73.7\%) and InRad (70.8\%) can also be classified as 
high. Applying the same criteria, it is clear that the $\mathrm{R}^{2}$ of Acap (1.7\%) is a small coefficient of determination whereas the $\mathrm{R}^{2}$ DIn $(16.3 \%)$ is average effect (Figure 2).

\section{(Figure 2)}

\section{COEFFICIENTS OF DETERMINATION ( $\left.{ }^{2}\right)$}

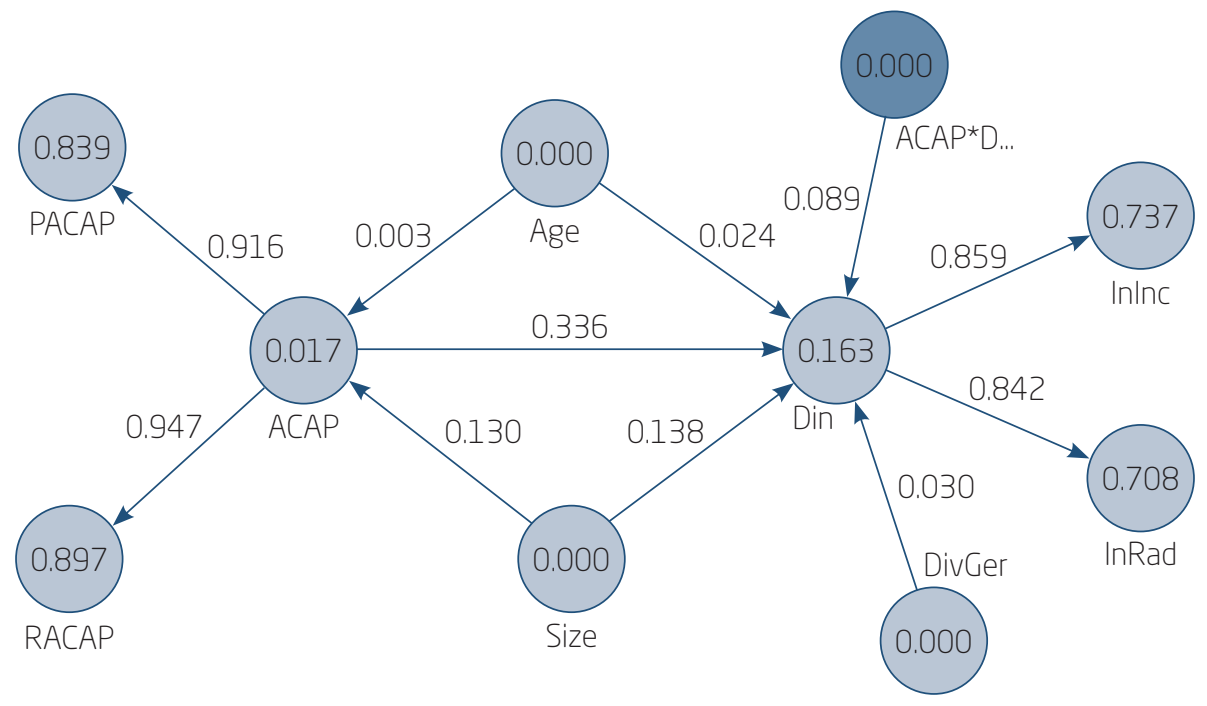

Note: Indicators of latent variables are hidden.

Source: Elaborated by the authors.

In the simulation, omitting the distance of 7 , it was found that all $\mathrm{Q}^{2}$ values are greater than zero, thus verifying that the models have predictive validity. A similar situation was observed in the adjustment quality indicator $\mathrm{f}^{2}$, in which all LV feature value greater than 0.35 , indicating that all constructs are important for general adjustment of the estimated model in this study.

\section{DISCUSSION}

As shown in Table 2, the hypothesis H1 tested in this study, was supported. However, the hypothesis $\mathrm{H} 2$, indicating generational diversity in the management of family firms as a moderator in the relationship between Acap and innovation performance, did not find sufficient empirical support. 


\section{(Table 2)}

VALIDATION RESULTS OF THE HYPOTHESES

\begin{tabular}{cccccc}
\hline Hypotheses & $\begin{array}{c}\text { Structural } \\
\text { relations }\end{array}$ & $\begin{array}{c}\text { Structural } \\
\text { coefficient }\end{array}$ & $\begin{array}{c}\text { Standard } \\
\text { error }\end{array}$ & t-Student & Results \\
\hline H1 & ACAP -> DIn & 0.3359 & 0.0544 & $6.1784^{\star \star \star *}$ & Supported \\
\hline H2 & ACAP * DivGer -> DIn & 0.0887 & 0.0897 & 0.9883 & Not supported \\
\hline \hline
\end{tabular}

Source: Elaborated by the authors.

$\star \star \star=$ significance level $1 \%(=>2.58)$.

The relationships developed and supported by the empirical part support the results of Zahra and George (2002) in several aspects. First, Acap is configured as an important predictor of innovation performance (H1), suggesting a recursive relationship among the constructs; i.e., the absorptive capacity helps the extent of innovation. In other words, innovation produces knowledge that becomes part of company's Acap, and the higher its frequency to innovate in an area, the greater its Acap in this area (Van den Bosch, Volberda, \& Boer, 1999; Lane et al., 2006; Kostopolos et al., 2011), creating a self-enhancing circle.

Contrary to expectations, the hypothesis suggesting that the simultaneous involvement of several generations in the management of family firms would be configured as a significant moderator between Acap, and the innovation performance $(\mathrm{H} 2)$ did not find empirical support in this study. This result contradicts previous studies that emphasize the importance of the involvement of different generations as a driving force for change and innovation, giving these companies a competitive advantage (Litz \& Kleysen, 2001; Zahra, 2005; Zahra et al., 2007; Kellermanns, Eddleston, Barnett, $\&$ Pearson, 2008; Cruz \& Nordqvist, 2012). Likewise, the result contrary to the studies made by Salvato (2004) and Chirico et al. (2011) to the extent that they report the generational diversity as a rich environment for the exchange of knowledge, provides a recombination and development of new resources and capabilities.

A possible explanation for this result may be the fact that in both groups (family firms with generational diversity versus family firms without generational diversity) the management and, therefore, the strategic decisions of company are under strong influence of the founder. This profile can be verified since the firms with several generations of family management are concentrated in the first and second generations (34.85\%) and, in turn, 
firms that do not have the generational diversity, are the first generation $(36.51 \%)$, and therefore a difference between the groups was not supported. This explanation is made possible, when taking into account what Kellermanns et al. (2012) name this in their studies as "founder effect", i.e., when in family firms decisions of the founding generations (or founder(s)) are superior to the innovative behavior of multigenerational firms.

\section{FINAL CONSIDERATIONS, LIMITATIONS, AND SUGGESTIONS FOR FUTURE INVESTIGATIONS}

Therefore, this research aimed to analyze the capacity of family firms to absorb relevant information from the external environment, and incorporate them in their innovative activities. Also, it tries to understand whether, and to what extent, the generational diversity in firm management, is configured as an important resource for firms.

The results of this study allow us to recognize Acap as an important predictor of innovation performance of family firms. Conversely, the involvement of several generations in the management of family firms is not set as a significant moderator between Acap and innovation performance.

In light of this information, there are some considerations to be made. First, this result seems to reveal the heterogeneous nature of these companies, showing that not all family firms are equally able to exploit its resources and capabilities, in this case, those resulting from the interaction among the generations of the family (Ling \& Kellermans, 2010; Sharma \& Salvato, 2011; Nordqvist, Sharma, \& Chirico, 2014). Indeed, family firms represent a unique setting since they are formed by the overlapping of complex systems - family, ownership and management - and one of the main explanations for the sustainability of these companies may be in the search for balance between tradition and renewal (Mahmoud-Jouini \& Mignon, 2009; Kellermanns et al., 2012).

This balance is not an easy task for the family firms since many firms may have the tendency to resort to search routines already known and rooted, which may impair the perception of other opportunities. The problem arises when these routines may no longer be sufficient in the case of a constantly changing environment. In this way, it seems essential that family firms develop capabilities that will allow the strengthening of existing elements in the firm, but they also can recognize when and how to modify them, allowing new capabilities to be created. Thus, it is understood that Acap, being 
a dynamic capability, plays an important role in achieving this balance, since it allows firms to access new knowledge, new partnerships, and perception of new market niches.

Finally, it is important to refer to the authors whose works are guiding the theme of this investigation. In their studies, they point out that Acap is not an end in itself, it is an essential prerequisite to implement innovation processes, being a mean for the firm to achieve a sustainable competitive advantage (Cohen \& Levinthal, 1990; Zahra \& George, 2002).

It is believed that the results of this study contribute to the literature in several ways. First of all, this study contributes to the evolution and consolidation of Acap, reinforcing it as an important investigative element as well as its importance in the innovation process. Another contribution of this study refers to the fact that it fills an important gap in the research on family firms. Considering the generational diversity in the management of these firms, the study and results deepen our understanding of the essential features of family firms and analyze the innovation in an intergenerational perspective.

It is believed that these results reinforce what some authors describe when highlight in their studies that resources by itself does not create competitive advantage, since it is necessary to be managed effectively for its value creation potential to be achieved (Habbershon, Williams, \& Macmillan, 2003; Zahra, Sapienza, \& Davidsson, 2006; Carnes \& Ireland, 2013; Zahra, 2016).

From a practical point of view, the results of this research could serve as an important strategic tool for family firms. Thus, it is expected that this study will help family firm managers understand how to maximize their performance results in innovation by promoting synergies between generations. This effort will allow family members to interact intensely and, from that, they can take advantage of complementary knowledge to develop new products.

This study presented some limitations. Firstly, it is based on a sample of Brazilian family firms. Thus, the results should be interpreted with caution, since they may not apply to family firms from other countries. Secondly, there is an issue with respect to the representativeness of individual responses of families that control the companies investigated here. Although the internet is considered an effective source to data collection (Malhotra, 2004), it is known that each existing difficulty in the process may result in discouragement from those who are not already highly motivated to contribute to the study. Therefore, factors, such as the lack of ability with technology, impersonality, or safety devices in the e-mail server of the firms have 
blocked the receipt of the questionnaire link, which may have contributed to the fact that potential respondents have declined the invitation by being afraid to open the link sent.

Another limitation refers on the size of the sample used. Nevertheless, given the characteristics of this study, the sample allowed to achieve significant analysis results. Therefore, it is recommended that future studies use larger samples. Finally, the data were collected and analyzed in this study are transversal data, i.e., they reflect the situation of firms at the time the study was conducted.

As a suggestion for future research, other researchers should consider that the multigenerational interaction requires from family firms the development of capacities aimed at combining the knowledge bases that reside in different generations. As a result, longitudinal studies on family firms could also help clarify the impact of changes in family and ownership, especially the transfer of knowledge among generations, and how it affects innovation and even their performance. It is hoped that the results presented here will encourage future researchers to use innovative methodologies to identify potential moderating variables that may have a significant effect on the relationship between Acap and family firms' innovation performance, such as, entrepreneurial orientation and owner family dynamics.

\section{CAPACIDADE DE ABSORÇÃO - UMA ANÁLISE NO CONTEXTO DAS EMPRESAS FAMILIARES BRASILEIRAS}

\section{RESUMO}

Objetivo: Esta investigação tem como objetivo analisar a capacidade das empresas familiares de absorver informações relevantes do ambiente externo e de incorporá-las em suas atividades inovadoras. Busca-se ainda compreender se, e em que medida a diversidade geracional na gestão da empresa, se configura como um importante recurso.

Originalidade/lacuna/relevância/implicações: Apesar da relevância do tema, poucos estudiosos exploraram a relação entre capacidade de absorção (Acap) e empresas familiares. Por outro lado, a relevância econômica dessas empresas é relatada, por exemplo, em Leone (2005) e Machado, Grzybovski, Teixeira e Silva (2013) cujos os autores citam que aproximadamente $90 \%$ das empresas brasileiras são controladas por famílias, sendo o segmento empresarial o que mais cresce. 
Principais aspectos metodológicos: A amostra é composta por 241 empresas familiares. Utiliza-se o software SmartPLS para a modelagem de equações estruturais.

Síntese dos principais resultados: Os resultados permitem reconhecer a Acap como um importante preditor do desempenho em inovação das empresas familiares. Contrariamente ao esperado, o envolvimento de várias gerações na gestão de empresas familiares não é um moderador significativo entre Acap e desempenho em inovação.

Principais considerações/conclusões: Este estudo preenche uma lacuna importante nas investigações sobre empresas familiares, na medida em que ao levar em consideração a diversidade geracional na gestão dessas empresas, seus resultados aprofundam a discussão sobre as características essenciais de um negócio familiar, e analisam a inovação sob uma perspectiva intergeracional.

\section{PALAVRAS-CHAVE}

Capacidade de absorção. Empresa familiar. Diversidade geracional. Desempenho em inovação. Capacidade dinâmica.

\section{$\int$ CAPACIDAD DE ABSORCIÓN: UN ANÁLISIS EN EL CONTEXTO DE LAS EMPRESAS FAMILIARES BRASILEÑAS}

\section{RESUMEN}

Objetivo: Esta investigación tiene como objetivo analizar la capacidad de las empresas familiares para absorber la información relevante del ambiente externo, y incorporarlas en sus actividades de innovación. También trata de entender si, y en qué medida, la diversidad generacional en la gestión de la empresa se configura como un recurso importante.

Originalidad/laguna/relevancia/implicaciones: A pesar de la importancia del tema, algunos estudiosos exploraron la relación entre la capacidad de absorción (Acap) y la empresa familiar. Por otra parte, se informó sobre la importancia económica de estas empresas familiares, por ejem- 
plo, en Leone (2005) y Machado, Grzybovski, Teixeira y Silva (2013) cuyos los autores citan que aproximadamente $90 \%$ de las empresas brasileñas son controladas por familias, siendo el segmento de negocios de más rápido crecimiento.

Principales aspectos metodológicos: La muestra se compone de 241 empresas familiares. Se utilizó en este estudio el software SmartPLS para el modelado de ecuaciones estructurales.

Sintesis de los principales resultados: Los resultados nos permiten reconocer la ACAP como un importante predictor del desempeño en innovación de las empresas familiares. Contrariamente a lo esperado, la participación de muchas generaciones en la gestión de la empresa familiar no es un moderador significativo entre ACAP y desempeño en innovación.

Principales consideraciones/conclusiones: Este estudio llena un vacío importante en la investigación de las empresas familiares. Cuando se tiene en cuenta la diversidad generacional en la gestión de la empresa, sus resultados profundizan la discusión sobre las características esenciales de una empresa familiar, y analizan la innovación en una perspectiva intergeneracional.

\section{PALABRAS CLAVE}

Capacidad de absorción. Empresa familiar. Diversidad generacional. Desempeño en innovación. Capacidad dinámica.

\section{$\int$ REFERENCES}

Astrachan, J. H., \& Kolenko, T. A. (1994). A neglected factor explaining family business success: human resource practices. Family Business Review, 7(3), 251-262. DOI: 10.1111/j.1741-6248.1994.00251.x.

Becker, J., Klein, K., \& Wetzels, M. (2012). Hierarchical latent variable models in PLS-SEM: guidelines for using reflective-formative type models. Long Range Planning, 45(5-6), 359-394. DOI: 10.1016/j.lrp.2012.10.001.

Block, J. H. (2012). R\&D investments in family and founder firms: an agency perspective. Journal of Business Venturing, 27(2), 248-265. DOI: 10.1016/j. jbusvent.2010.09.003. 
Burcharth, A. L. L. de A., Lettl, C., \& Ulhøi, J. P. (2015). Extending organizational antecedents of absorptive capacity: organizational characteristics that encourage experimentation. Technological Forecasting and Social Change, 90(2015), 269-284. DOI: 10.1016/j.techfore.2013.12.024.

Camisón, C., \& Forés, B. (2010). Knowledge absorptive capacity: new insights for its conceptualization and measurement. Journal of Business Research, 63 (7), 707-715. DOI: 10.1016/j.jbusres.2009.04.022.

Carnes, C. M., \& Ireland, R. D. (2013). Familiness and innovation: resource bundling as the missing link. Entrepreneurship Theory and Practice, 37(6), 1399-1419. DOI: 10.1111/etap.12073.

Cennamo, C., Berrone, P., Cruz, C., \& Gómez-Mejía, L. R. (2012). Socioemotional wealth and proactive stakeholder engagement: why family-controlled firms care more about their stakeholders. Entrepreneurship Theory and Practice, 36(Special), 1153-1173. DOI: 10.1111/j.1540-6520.2012.00543.x.

Chirico, F., Sirmon, D. G., Sciascia, S., \& Mazzola, P. (2011). Resource orchestration in family firms: investigating how entrepreneurial orientation, generational involvement, and participative strategy affect performance. Strategic Entrepreneurship Journal, 5(4), 307-326. DOI: 10.1002/sej.121.

Choi, Y. R., Zahra, S. A., Yoshikawa, T., \& Han, B. H. (2015). Family ownership and R\&D investment: the role of growth opportunities and business group membership. Journal of Business Research, 68(5), 1053-1061. DOI: 10.1016/j.jbusres.2014.10.007.

Chrisman, J., \& Patel, P. (2011). Variations in R\&D investments of family and non-family firms: behavioral agency and myopic loss aversion perspectives. Academy of Management Journal, 55(4), 976-997. DOI: 10.5465/ amj.2011.0211.

Classen, N., Van Gils, A., Bammens, Y., \& Carree, M. (2012). Accessing resources from innovation partners: the search breadth of family SMEs. Journal of Small Business Management, 50(2), 191-215. DOI: 10.1111/j.1540627X.2012.00350.x.

Cohen, J. (1977). Statistical power analysis for the behavioral sciences. Revised Edition. New York: Academic Press.

Cohen, W. M., \& Levinthal, D. A. (1989). Innovation and learning: the two faces of R\&D. Economic Journal, 99(397), 569-596.

Cohen, W. M., \& Levinthal, D. A. (1990). Absorptive-capacity - a new perspective on learning and innovation. Administrative Science Quarterly, 35(1), 128-152. 
Cruz, C., \& Nordqvist, M. (2012). Entrepreneurial orientation in family firms: a generational perspective. Small Business Economics, 38(1), 33-49. DOI: 10.1007/s11187-010-9265-8.

DeVellis, R. F. (2012). Scale development: theory and applications (3a ed). Thousand Oaks: SAGE.

European Family Businesses. (2014). Families in business for the long term. Retrieved May 23, 2015, from www.europeanfamilybusinesses.eu.

Faul, F., Erdfelder, E., Lang, A.-G., \& Buchner, A. (2007). G*Power 3: a flexible statistical power analysis program for the social, behavioral, and biomedical sciences. Behavior Research Methods, 39(2), 175-191.

Ferreira, J., Raposo, M., \& Fernandes, C. (2013). Does innovativeness of knowledge-intensive business services differ from other industries? The Service Industries Journal, 33(7-8), 734-748. DOI: 10.1080/02642069.2013.740462.

Ferreira, J., Fernandes, C., Alves, H., \& Raposo, M. (2015). Drivers of innovation strategies: testing the Tidd and Bessant (2009) model. Journal of Business Research, 68(7), 1395-1403. DOI: org/10.1016/j.jbusres.2015.01.021.

Federação das Indústrias do Estado do Rio Grande do Sul. (2015). Cadastro das Indústrias, Fornecedores e Serviços do Rio Grande do Sul. Porto Alegre: Unidade de Estudos Técnicos, Sistema FIERGS.

Filser, M., Brem, A., Gast, J., Kraus, S., \& Calabrò, A. (2016). Innovation in family firms: examining the inventory and mapping the path. International Journal of Innovation Management, 20(6), 1-39. DOI: 10.1142/S1363919616500547. Flatten, T. C., Engelen, A., Zahra, S. A., \& Brettel, M. (2011). A measure of absorptive capacity: scale development and validation. European Management Journal, 29(2), 98-116. DOI: 10.1016/j.emj.2010.11.002.

Forés, B., \& Camisón, C. (2016). Does incremental and radical innovation performance depend on different types of knowledge accumulation capabilities and organizational size? Journal of Business Research, 69(2), 831-848. DOI: 10.1016/j.jbusres.2015.07.006.

Fosfuri, A., \& Tribó, J. (2008). Exploring the antecedents of potential absorptive capacity and its impact on innovation performance. Omega, 36(2), 173-187. DOI: 10.1016/j.omega.2006.06.012.

Garver, M. S., \& Mentzer J. T. (1999). Logistics research methods: Employing structural equation modelling to test for construct validity. Journal of Business Logistics, 20(1), 33-57.

Gersick, K., Davis, J. A., Hampton, M., \& Lansberg, I. (2006). De geração para geração: ciclos de vida das empresas familiares. Rio de Janeiro: Elsevier. 
Gómez-Mejía, L. R., Campbell, J. T., Martin, G., Hoskisson, R. E., Makri, M., \& Sirmon, D. G. (2014). Socioemotional wealth as a mixed gamble: revisiting family firm R\&D investments with the behavioral agency model. Entrepreneurship Theory and Practice, 38(6), 1351-1374.

Gómez-Mejía, L. R., Takács Haynes, K., Núñez-Nickel, M., Jacobson, K. J. L., \& Moyano-Fuentes, J. (2007). Socioemotional wealth and business risks in family-controlled firms: evidence from Spanish olive oil mills. Administrative Science Quarterly, 52(1), 106-137. DOI: 10.2189/asqu.52.1.106.

Habbershon, T. G., \& Williams, M. L. (1999). A resource-based framework for assessing the strategic advantages of family firms. Family Business Review, 12(1), 1-25. DOI: 10.1111/j.1741-6248.1999.00001.x.

Habbershon, T. G., Williams, M. L., \& Macmillan, I. C. (2003). A unified systems theory of family firm performance. Journal of Business Venturing, 18(4), 451-465. DOI: 10.1016/S0883-9026 (03) 00053-3.

Hair, J. F., Tatham, R. L., Anderson, R. E., \& Black, W. (2005). Análise multivariada de dados. 5 a ed. Porto alegre: Bookman.

Hair, J. F., Hult, G. T. M., Ringle, C. M., \& Sarstedt, M. (2014). A primer on partial least squares structural equation modeling (PLS-SEM). Thousand Oaks: Sage.

Hernández-Perlines, F., Moreno-Garcia, J., \& Yáñez-Araque, B. (2016). Using fuzzy-set qualitative comparative analysis to develop an absorptive capacity-based view of training. Journal of Business Research, 69(4), 1510-1515. DOI: $10.1016 /$ j.jbusres.2015.10.133.

Ingram, A. E., Lewis, M. W., Barton, S., \& Gartner, W. B. (2016). Paradoxes and innovation in family firms: the role of paradoxical thinking. Entrepreneurship Theory and Practice, 40(1), 161-176. DOI: 10.1111/etap.12113.

Jansen, J. J. P., Van Den Bosch, F. A. J., \& Volberda, H. W. (2005). Managing potential and realized absorptive capacity: how do organizational antecedentes matter. Academy of Management Journal, 48(6), 999-1015. DOI: 10.5465/ AMJ.2005.19573106.

Jones, O. (2006). Developing absorptive capacity in mature organizations: the change agent's role. Management Learning, 37(3), 355-376. DOI: 10.1177/ 1350507606067172.

Kellermanns, F. W., \& Eddleston, K. A. (2006). Corporate entrepreneurship in family firms: a family perspective. Entrepreneurship Theory and Practice, 30(6), 809-830. DOI: 10.1111/j.1540-6520.2006.00153.x. 
Kellermanns, F. W., Eddleston, K. A., Barnett, T., \& Pearson, A. (2008). An exploratory study of family member characteristics and involvement: effects on entrepreneurial behavior in the family firm. Family Business Review, 21 (1), 1-14. DOI: 10.1111/j.1741-6248.2007.00107.x.

Kellermanns, F. W., Eddleston, K., Sarathy, R., \& Murphy, F. (2012). Innovativeness in family firms: a family influence perspective. Small Business Economics, 38(1), 85-101. DOI: 10.1007/s11187-010-9268-5.

Kellermanns, F. W., Eddleston, K., \& Zellweger, T. (2012). Extending the socioemotional wealth perspective: a look at the dark side. Entrepreneurship Theory and Practice, 36(6), 1175-1182. DOI: 10.1111/j.1540-6520.2012.00544.x.

König, A., Kammerlander, N., \& Enders, A. (2013). The family innovator's dilemma: how family influence affects the adoption of discontinuous technologies by incumbent firms. Academy of Management Review, 38(3), 418-441. DOI: 10.5465/amr.2011.0162.

Kostopoulos, K., Papalexandris A., Papachroni M., \& Ioannou, G. (2011). Absorptive capacity, innovation, and financial performance. Journal of Business Research, 64(12), 1335-1343. DOI: 10.1016/j.jbusres.2010.12.005.

Kraiczy, N., Hack, A., \& Kellermanns, F. (2014). New product portfolio performance in family firms. Journal of Business Research, 67(6), 1065-1073. DOI: 10.1016/j.jbusres.2013.06.005.

Lane, P. J., Koka, B., \& Pathak, S. (2006). The reification of absorptive capacity: a critical review and rejuvenation of the construct. Academy of Management Review, 31 (4), 833-863. DOI: 10.5465/AMR.2006.22527456.

Leal-Rodríguez, A. L., Roldán, J. L., Ariza-Montes, J. A., \& Leal-Millán, A. (2014). From potential absorptive capacity to innovation outcomes in project teams: the conditional mediating role of the realized absorptive capacity in a relational learning context. International Journal of Project Management, 32 (6), 894-907. DOI: 10.1016/j.ijproman.2014.01.005.

Leone, N. (2005). Sucessão na empresa familiar: preparando as mudanças para garantir sobrevivência no mercado globalizado. São Paulo: Atlas.

Ling, Y., \& Kellermans, F. (2010). The effects of family firm specific sources of TMT diversity: the moderating role of information exchange frequency. Journal of Management Studies, 47(2), 322-344. DOI: 10.1111/j.1467-6486.2009.00893.x.

Litz, R. A., \& Kleysen, R. F. (2001). Your old men shall dream dreams, your young men shall see visions: toward a theory of family firm innovation with help from the Brubeck family. Family Business Review, 14(4), 335-351. DOI: 10.1111/j.1741-6248.2001.00335.x. 
Machado, R., Grzybovski, D., Teixeira, E., \& Silva, M. (2013). Governança de pequenas empresas familiares brasileiras: aspectos a considerar no modelo adotado. Revista de Ciências da Administração, 1 (1), 198-210. DOI: hndoi. org/10.5007/2175-8077.2013v15n37p198.

Mahmoud-Jouini, S. B., \& Mignon, S. (2009). Entrepreneuriat familial et stratégies de pérennité: contribution au concept d'innovation prudentielle. Management international/International Management/Gestión Internacional, 14(1), 25-41. DOI: 10.7202/039137ar.

Malhotra, N. (2004). Pesquisa de marketing: uma orientação aplicada. 3a ed. Porto Alegre: Bookman.

Marôco, J. (2014). Análise Estatística com o SPSS Statistics. Lisboa: ReportNumber.

McCann, B. T, \& Folta, T. B. (2008). Location matters: where we have been and where we might go in agglomeration research. Journal of Management, 34(3), 531-565. DOI: 10.1177/0149206308316057.

Miller, D., Le Breton-Miller, I., \& Lester, R. H. (2010). Family ownership and acquisition behavior in publicly-traded companies. Strategic Management Journal, 31 (2), 201-223. DOI: 10.1002/smj.802.

Miller, D., Le Breton-Miller, I., \& Lester, R. H. (2012). Family firm governance, strategic conformity, and performance: institutional vs strategic perspectives. Organization Science, 24(1), 189-209. DOI: 10.1287/orsc.1110.0728.

Murovec, N., \& Prodan, I. (2009). Absorptive capacity, its determinants, and influence on innovation output: cross-cultural validation of the structural model. Technovation, 29(12), 859-872. DOI: 10.1016/j.technovation. 2009.05.010.

Nieto, M., \& Quevedo, P. (2005). Absorptive capacity, technological opportunity, knowledge spillovers, and innovative effort. Technovation, 25(10), 1141-1157. DOI: 10.1016/j.technovation.2004.05.001.

Nordqvist, M., \& Melin, L. (2010). Entrepreneurial families and family firms. Entrepreneurship \& Regional Development, 22(3-4), 211-239. DOI: 10.1080/ 08985621003726119.

Nordqvist, M., Sharma, P., \& Chirico, F. (2014). Family firm heterogeneity and governance: a configuration approach. Journal of Small Business Management, 52 (2), 192-209. DOI: 10.1111/jsbm.12096.

Patterson, W., \& Ambrosini, V. (2015). Configuring absorptive capacity as a key process for research intensive firms. Technovation, 36/37, 77-89. DOI: 10.1016/j.technovation.2014.10.003. 
Ringle, C. M., Wende, S., \& Will, A. (2005). SmartPLS 2.0.M3. Hamburg: SmartPLS. Retrieved January 22, 2016, from http://www.smartpls.de.

Ringle, C. M., Silva, D., \& Bido, D. (2014). Modelagem de equações estruturais com utilização do SMARTPLS. Revista Brasileira de Marketing - ReMark, 13(2). DOI: 10.5585/remark.v13i2.2717.

Roessl, D. (2005). Family businesses and interfirm cooperation. Family Business Review, 18(3), 203-214. DOI: 10.1111/j.1741-6248.2005.00042.x.

Salvato, C. (2004). Predictors of entrepreneurship in family firms. Journal of Private Equity, 7(3), 68-76. DOI: 10.3905/jpe.2004.412339.

Sarstedt, M., \& Ringle, C. M. (2010). Treating unobserved heterogeneity in PLS path modeling: a comparison of FIMIX-PLS with different data analysis strategies. Journal of Applied Statistics, 37(8), 1299-1318. DOI: 10.1080/02664760903030213.

Schulze, W. S., \& Kellermanns, F. W. (2015). Reifying socioemotional wealth. Entrepreneurship Theory and Practice, 39(3), 447-459. DOI: 10.1111/etap.12159.

Sciascia, S., Mazzola, P., \& Chirico, F. (2013). Generational involvement in the top management team of family firms: exploring nonlinear effects on entrepreneurial orientation. Entrepreneurship Theory and Practice, 37(1), 69-85. DOI: 10.1111/j.1540-6520.2012.00528.x.

Sharma, P., \& Salvato, C. (2011). Commentary: exploiting and exploring new opportunities over life cycle stages of family firms. Entrepreneurship Theory and Practice, 35(6), 1199-1205. DOI: 10.1111/j.1540-6520.2011.00498.x.

Sørensen, J. B., \& Stuart, T. E. (2000). Aging, obsolescence and organizational innovation administrative. Science Quarterly, 45(1), 81-112. DOI: $10.2307 / 2666980$.

Tidd, J., \& Bessant, J. (2015). Gestão da Inovação. (5a ed.). Porto Alegre: Bookman.

Van Den Bosch, F. A., Volberda, H. W., \& Boer, M. D. (1999). Coevolution of firm absorptive capacity and knowledge environment: organizational forms and combinative capabilities. Organization Science, 10(5), 551-568. DOI: http://dx.doi.org/10.1287/orsc.10.5.551.

Vega-Jurado, J., Gutiérrez-Gracia, A., \& Fernándes-De-Lucio, I. (2008). Analyzing the determinants of firm's absorptive capacity: beyond R\&D. $R \& D$ Management, 38(4), 392-405. DOI: 10.1111/j.1467-9310.2008.00525.x.

Vega-Jurado, J., Gutiérrez-Gracia, A., Fernández-De-Lucio, I., \& Manjarrés-Henríquez, L. (2008). The effect of external and internal factors on firms' product innovation. Research Policy, 37(4), 616-632. DOI: 10.1016/j.respol. 2008.01.001. 
Vicentin, F. O. P. (2015). Alianças e a sua contribuição no desenvolvimento da capacidade de absorção e no desempenho inovador das empresas dedicadas à biotecnologia. Tese de doutorado, Faculdade de Economia, Administração e Contabilidade de Ribeirão Preto da Universidade de São Paulo, São Paulo, SP, Brasil. Retrieved March 29, 2016, from http://www.teses.usp.br/teses/disponiveis/96/96132/tde-20072015-144106/pt-br.php.

Vinding, A. L. (2006). Absorptive capacity and innovative performance: a human capital approach. Economics of Innovation and New Technology, 15(4-5), 507-517. DOI: 10.1080/10438590500513057.

Vries, M., Carlock, R. S., \& Florent-Treacy, E. (2009). A empresa familiar no divã: uma perspectiva psicológica. Porto Alegre: Bookman.

Wang, C. L., Senaratne, C., \& Rafiq, M. (2015). Success traps, dynamic capabilities and firm performance. British Journal of Management, 26(1), 26-44. DOI: 10.1111/1467-8551.12066.

Ward, J. L. (2004). Perpetuating the family business: 50 lessons learned from longlasting, successful families in business. Basingstoke: Palgrave Macmillan.

Wetzels, M., Odekerken-Schröder, G., \& Oppen, C. V. (2009). Using PLS path modeling for assessing hierarchical construct models: guidelines and empirical illustration. MIS Quarterly, 33(1), 177-195, 2009.

Winter, S. G. (2000). The satisfying principle in capability learning. Strategic Management Journal, 21 (10/11), 981-996, 2000.

Zahra, S. A., \& George, G. (2002). Absorptive capacity: a review, reconceptualization, and extension. Academy of Management Review, 27(2), 185-203. DOI: 10.5465/AMR.2002.6587995.

Zahra, S. A. (2003). International expansion of U.S. manufacturing family businesses: the effect of ownership and involvement. Journal of Business Venturing, 18(4), 495-512. DOI: 10.1016/S0883-9026(03)00057-0.

Zahra, S. A., Hayton, J. C., \& Salvato, C. (2004). Entrepreneurship in family vs nonfamily firms: A resource-based analysis of the effect of organizational culture. Entrepreneurship Theory and Practice, 28(4), 363-381.

Zahra, S. A. (2005). Entrepreneurial risk taking in family firms. Family Business Review, 18(1), 23-40. DOI: 10.1111/j.1741-6248.2005.00028.x.

Zahra, S. A., Sapienza, H. J., \& Davidsson, P. (2006). Entrepreneurship and dynamic capabilities: a review, model and research agenda. Journal of Management Studies, 43(4), 917-955. DOI: 10.1111/j.1467-6486.2006.00616.x.

Zahra, S. A., Neubaum, D. O., \& Larrañeta, B. (2007). Knowledge sharing and technological capabilities: the moderating role of family involvement. Journal of Business Research, 60(10), 1070-1079. DOI: 10.1016/j.jbusres.2006.12.014. 
Zahra, S. A., Hayton, J. C., Neubaum, D. O., Dibrell, C., \& Craig, J. (2008). Culture of family commitment and strategic flexibility: the moderating effect of stewardship. Entrepreneurship Theory and Practice, 32(6), 1035-1054. DOI: 10.1111/j.1540-6520.2008.00271.x.

Zahra, S. A. (2016). Developing theory-grounded family business research: some suggestions. Journal of Family Business Strategy, 7(1), 3-7. DOI: 10.1016/j. jfbs.2015.10.004. 